\title{
CAUSES AND FINANCIAL CONSEQUENCES OF FLIGHT DELAYS IN CZECH REPUBLIC
}

\author{
[Př́rčiny a finanční důsledky zpoždění letů v České republice] \\ Martina Zámková ${ }^{1}$, Martin Prokop ${ }^{2}$ \\ ${ }^{1}$ Vysoká škola polytechnická Jihlava, Tolstého 16, 58601 Jihlava \\ Email:martina.zamkova@centrum.cz. \\ ${ }^{2}$ Vysoká škola polytechnická Jihlava, Tolstého 16, 58601 Jihlava \\ Email:martin.prokop@vspj.cz
}

\begin{abstract}
The article aims to analyse causes of flight delays in Czech Republic and to assess their financial consequences for airlines. Methods of multidimensional statistics were used for data processing, specifically independence tests in contingency tables and correspondence analysis. We see the biggest savings in assurance of excellence technical condition of aircraft. We would recommend idea of alternative aircraft (without flight plan) especially in case of long delays, of which the monitored airline has a large number and has to pay high financial amounts due to financial compensations for passengers. It is also possible according to our analysis to prevent longer delays by cooperation with flexible suppliers and appropriate form of penalties. Other causes of long delays were defined, but they can be hardly influenced, for example weather in destinations, transport of disabled people, necessity of treatment of passenger with healthy problems etc., these are delay reasons that doesn't mean necessity of paying out financial compensation, but they cause chaining of delays.
\end{abstract}

Keywords: airlines delay codes, contingency tables, correspondence analysis, Pearson chi-squared test.

JEL classification: C30, R40

Doručeno redakci: 23.9.2015; Recenzováno: 1.10.2015; 6.10.2015; Schváleno k publikování: 15.12.2015

\section{Úvod}

V př́ípadě významného zpoždění letu mají cestující při splnění podmínek právo na finanční odškodnění. Jedná se o poměrně vysoké částky, které činí vysoké nákladové položky pro letecké společnosti. Je tedy třeba eliminovat především dlouhá zpoždění, aby aerolinky nemusely tyto finanční náhrady cestujícím vyplácet. Současně mohou získat více spokojených zákazníků, nebot čekání na letištích není nikomu př́ijemné. Právním předpisem, který upravuje práva cestujících v letecké dopravě, je Nař́zení Evropského parlamentu a Rady (ES) č. 261/2004, podrobněji viz European Consumer Centre Czech Republic (2015).

Cílem tohoto článku je zhodnocení prí̌cin zpoždění letů na vybraných českých letištích (Praha, Brno, Ostrava) na základě kódů dle IATA ${ }^{1}$ upravených pro potřeby vybrané letecké společnosti působící v České republice. Pomocí testu nezávislosti v kontingenčních tabulkách byly zkoumány závislosti důvodů zpoždění na dalších faktorech. Následují doporučení, jak eliminovat prríčiny zpoždění letů a zmírnit tak finanční důsledky především ve formě finančních kompenzací cestujícím.

Primární data byla zkoumána $\mathrm{v}$ nejfrekventovanějším období pro vybranou leteckou společnost (1. 6. 2013 - 30. 9. 2013). Data obsahovala informace o délce zpoždění i prríčinách zpoždění dle IATA kódů, které byly společností upraveny pro jejich potřeby, viz tabulka 1.

\footnotetext{
${ }^{1}$ IATA - mezinárodní organizace sdružující letecké dopravce
} 
Podstatná část dat je kategoriálních nebo vhodných ke kategorizaci. Data byla získána z interní databáze sledované letecké společnosti.

Jak již bylo uvedeno, finanční kompenzace jsou pro aerolinky skutečně velkou zátěží. V dnešní době již existují specializované společnosti, které vymáhají na leteckých společnostech tyto náhrady. Dokonce samy oslovují cestující zpožděných letů, kteří pro ně představují zdroj př́immu, účtují si okolo $27 \%$ z vymožené částky. Náhrady na jednoho cestujícího se mohou pohybovat mezi 250 - 600 EUR (tedy až 15500 Kč) podle délky letu. Dále je třeba si uvědomit, že ve flotile sledované letecké společnosti jsou provozována především letadla typu Boeing 737, popř. Airbus 320, která pojmou okolo 149 - 189 cestujících. Proto je pro leteckou společnost nutná eliminace dlouhých zpoždění, právě z důvodu nutnosti vyplácení finančních náhrad.

Tabulka 1: Kódy zpoždění dle IATA

\begin{tabular}{|l|l|}
\hline Kódy & Význam \\
\hline AIC & provozní důvody aerolinky \\
PB & zpoždění z důvodu cestujících a jejich zavazadel \\
ARH & zpoždění způsobené při odbaveni letadla dodavatelskými společnostmi - odbavení letadel, palivo, catering, ... \\
TAE & zpoždění způsobené technickou údržbou nebo závadou na letadle \\
FOC & zpoždění způsobené operačním řízením a letovou normou posádky \\
ATFMR & zpoždění způsobené řízením letového provozu \\
AGA & zpoždění z důvodu omezeni na letištích \\
R & reakční kódy - zpoždění způsobené zpožděním předcházejících letů \\
MISC & specifické zpoždění, nelze zahrnout do předchozích kategorií \\
\hline
\end{tabular}

Zdroj: Eurocontrol (2015)

A jak dlouhé musí být zpoždění, aby cestující měl nárok na péči ze strany dopravce? Jedná se o dvě hodiny nebo více $v$ prípadě letů o délce nejvýše $1500 \mathrm{~km}$, tř́i hodiny nebo více v prrípadě všech letů v EU delších než $1500 \mathrm{~km}$ a všech ostatních letů o délce od $1500 \mathrm{~km}$ do $3500 \mathrm{~km}$, př́padně čtyři hodiny nebo více u všech ostatních letů. Výše finančního odškodnění je pak při splnění předpokladů závislá právě na délce letu. Cestující má nárok na 250 EUR u všech letů o délce nejvýše 1500 kilometrů, 400 EUR u všech letů v rámci EU delších než $1500 \mathrm{~km}$ a u všech ostatních letů o délce od $1500 \mathrm{~km}$ do $3500 \mathrm{~km}$, popř́padě 600 EUR u všech ostatních letů. Uvedené částky může dopravce snížit na polovinu, pokud je cestujícím poskytnuto přesměrování a náhradní dopravou dosáhnou místo určení do určitého času, podrobněji viz European Consumer Centre Czech Republic (2015).

Zpoždění představuje komplikace pro cestující i letištní personál, problematiku řeší například článek autorů Wu, Truong (2014). Zabývá se srovnáním IATA kódů pro zpoždění letů s autory vyvinutým speciálním kódovacím systémem. Článek autorů Skorupski, Wierzbinska (2015) se zabývá potížemi vzniklými čekáním na opožděné cestující a hledáním optimální délky časového okamžiku, kdy je vhodné čekání na opozdilce ukončit. Dle článku autorů Forbes, Lederman, Tombe (2015) by pak bylo vhodné, aby aerolinky zveřejňovaly informace o množství zpožděných letů se zpožděním delším než 15 minut.

\section{Metodika}

Metoda korespondenční analýzy umožňuje grafickou technikou analyzovat vztah mezi kategoriemi jedné či více kategoriálních proměnných v kontingenčních tabulkách. Výsledkem analýzy je tzv. korespondenční mapa představující osy redukovaného souřadného systému, ve kterém jsou graficky zobrazeny jednotlivé kategorie obou proměnných. Pomocí nástrojů této metody je možné popsat asociace nominálních či ordinálních proměnných a získat 
grafické znázornění souvislostí ve vícerozměrném prostoru. Cílem této analýzy je redukovat mnohorozměrný prostor vektorů řádkových a sloupcových profilů při maximálním zachování informace z původních dat, viz Hebák a kol. (2007). Každý řádek a sloupec korespondenční tabulky můžeme zobrazit $\mathrm{v} c$-rozměrném resp. $r$-rozměrném prostoru se souřadnicemi rovnými hodnotám př́slušných profilů. Mezi jednotlivými body je vzdálenost definována jako chí-kvadrát vzdálenost. Vzdálenost mezi $i$-tým a $i$-tým řádkem je určena vztahem

$$
D\left(i, i^{\prime}\right)=\sqrt{\sum_{j=1}^{c} \frac{\left(r_{i j}-r_{i^{\prime} j}\right)^{2}}{c_{j}}},
$$

kde $r_{i j}$ jsou prvky matice rádkových profilů $\mathbf{R}$ a váhy $c_{j}$ odpovídají prvkům vektoru sloupcových zátěží $c^{T}$, který je navíc roven průměrnému sloupcovému profilu, tedy centroidu neboli těžišti sloupcových profilů $\mathrm{v}$ mnohorozměrném prostoru. Obdobně je definována vzdálenost mezi sloupci $j$ a $j$ ', váhy zde odpovídají prvkům vektoru ráádkových zátěží $r$ a sčítáme přes všechny řádky, viz Greenacre (1984).

Při analýze kategoriálních dat se dají jednoduchým způsobem znázornit vztahy mezi těmito daty pomocí kontingenční tabulky. Dle charakteru dat potom využíváme vhodné testy nezávislosti, viz Hendl (2006). Dle Řezankové (1997) pro př́pad kontingenční tabulky $r$ x $c$ ( $r$ je počet řádků, $c$ je počet sloupců) nejčastěji využíváme testovou statistiku Pearsonův chíkvadrát

$$
\chi^{2}=\sum_{i} \sum_{j} \frac{\left(n_{i j}-e_{i j}\right)^{2}}{e_{i j}},
$$

na získaná data se použije Pearsonův chí-kvadrát test o nezávislosti. Nulová hypotéza tohoto testu předpokládá nezávislost důvodů zpoždění na dalších sledovaných faktorech. Symbol $e_{i j}$ znamená očekávané četnosti pro př́pad nezávislosti a symbol $n_{i j}$ pozorované četnosti v kontingenční tabulce. Indexy $i$ a $j$ značí konkrétní řádek a sloupec kontingenční tabulky. Očekávané četnosti se vypočtou z kontingenční tabulky jako součin marginálních četností dělený celkovou četností. Statistika chí-kvadrát má za předpokladu nezávislosti asymptoticky rozdělení $\chi_{(r-1)(c-1)}^{2}$. Bližší informace viz Řezanková (2007), popř. Hindls (2003). Pomocí statistického softwaru Unistat a Statistica byla pro každou hypotézu vypočtena p-hodnota, která znamená nejnižší hladinu významnosti, na které lze zamítnout nulovou hypotézu o nezávislosti zkoumaných proměnných. Riziko nesprávného zamítnutí nulové hypotézy bylo stanoveno na $5 \%$. Pro použití Pearsonova chí-kvadrát testu je třeba splnit podmínku, aby maximálně $20 \%$ očekávaných četností bylo menších než 5, více viz Hendl (2006), Agresti (1990), popř. Anděl (2005).

Při prokázání závislosti byla zkoumána její intenzita pomocí Pearsonova kontingenčního koeficientu

$$
P=\sqrt{\frac{\chi^{2}}{\chi^{2}+n}} .
$$

Hodnota koeficientu leží v intervalu od nuly do jedné, hodnoty blízké nule značí nízkou intenzitu závislosti, hodnoty blízké jedné vysokou intenzitu závislosti.

\section{Výsledky výzkumu}

Ve sledovaném období (1. 6. 2013 - 30. 9. 2013) bylo uskutečněno celkem 5777 letů z Prahy (PRG), Brna (BRQ) a Ostravy (OSR). Z tohoto počtu odletů jich 33,7 \% mělo zpoždění. Nejvíce zpožděných letů bylo z Prahy (36 \%) a nejméně z Ostravy $(26,6 \%)$, což je zřejmě způsobeno hustotou provozu na jednotlivých letištích. V tabulce 2 je celá situace zachycena 
ve sledovaných nejfrekventovanějších měsících roku. Nejčastěji tedy zpoždění letů vzniká v červnu (36,6 \%) a září $(35,3 \%)$. Příčinou může být skutečnost, že v červnu a záŕí nejsou plně k dispozici všechna pronajatá letadla, společnost totiž zapůjčuje další stroje pouze na nejnutnějš́i období.

Tabulka 2: Kontingenční tabulka

\begin{tabular}{|l|c|c|c|}
\hline měsíc & počet letů z PRG, BRQ, OSR & zpožděno & procent. \\
\hline červen & 1389 & 509 & $36,6 \%$ \\
\hline červenec & 1557 & 473 & $30,4 \%$ \\
\hline srpen & 1540 & 508 & $33,0 \%$ \\
\hline záři & 1291 & 456 & $35,3 \%$ \\
\hline
\end{tabular}

Zdroj: vlastní výpočty

Pomocí Pearsonova chí-kvadrát testu nezávislosti jsme otestovali vztah mezi proměnnými značícími délku zpoždění a důvody zpoždění letů. Při testování nezávislosti byla vypočtena hodnota testové statistiky $\chi^{2}=218,02$ s p-hodnotou $p=0,00 . \mathrm{Na} 5 \%$ hladině významnosti tedy zamítáme nezávislost obou sledovaných proměnných. Charakter závislosti je patrný $\mathrm{z}$ relativních četností v kontingenční tabulce i z korespondenční mapy (viz tabulka 3, obrázek 1). Pearsonův koeficient kontingence je $P=0,3174$.

Tabulka 3: Kontingenční tabulka - Sloupcové relativní četnosti: Závislost délky zpoždění na důvodech zpoždění letů

\begin{tabular}{|l|c|c|c|}
\hline & $\mathbf{0 : 1 5}-\mathbf{0 : 3 0}$ & $\mathbf{0 : 3 1}-\mathbf{1 : 0 0}$ & $\mathbf{1 : 0 1}$ a více \\
\hline AIC & $12,66 \%$ & $15,71 \%$ & $21,73 \%$ \\
PB & $3,28 \%$ & $2,09 \%$ & $0,19 \%$ \\
ARH & $2,70 \%$ & $0,17 \%$ & $0,38 \%$ \\
TAE & $5,98 \%$ & $6,98 \%$ & $15,19 \%$ \\
FOC & $8,32 \%$ & $4,36 \%$ & $2,50 \%$ \\
ATFMR & $14,54 \%$ & $5,41 \%$ & $6,73 \%$ \\
AGA & $7,97 \%$ & $3,66 \%$ & $1,15 \%$ \\
R & $40,68 \%$ & $60,21 \%$ & $50,96 \%$ \\
MISC & $3,87 \%$ & $1,40 \%$ & $1,15 \%$ \\
\hline
\end{tabular}

Zdroj: vlastní výpočty

Důvod AIC převažuje dle provedené analýzy u delších zpoždění nad 1 hodinu (22 \%). Dá se říci, že četnost tohoto důvodu roste s délkou zpoždění. Do této kategorie spadají např́íklad i důvody typu přeprava tělesně postižených a nutná zdravotní péče pro cestující s náhlým zdravotním problémem. Tyto důvody mohou způsobit delší zpoždění, např. technické mezipřistání, apod. Důvody PB a ARH se celkově vyskytují velmi zřídka, o něco častější jsou u krátkých zpoždění. Dodavatelské společnosti se tedy zřejmě snaží minimalizovat zpoždění z jejich viny, jinak mohou být penalizovány. Důvod TAE výrazněji převažuje u delších zpoždění nad 1 hodinu (15\%). Je logické, že řešení technické závady většinou vyžaduje více času. Důvod FOC převažuje u krátkých zpoždění do půl hodiny $(8 \%)$ a dá se říci, že s délkou zpoždění četnost jeho výskytu klesá. Palubní personál se tedy snaží také zajistit včasný odlet. Důvody ATFMR, AGA jsou výrazně častější u krátkých zpoždění do 30 min. (15\% a $8 \%$ ). Je zřejmé, že vzdušný prostor je regulován centrálním řízením, které se snaží o plynulý a ekonomický provoz. Důvod R se vyskytuje celkově velmi často, pohybuje od 40-60\%. 
Obrázek 1: Korespondenční analýza: Závislost délky zpoždění na důvodech zpoždění

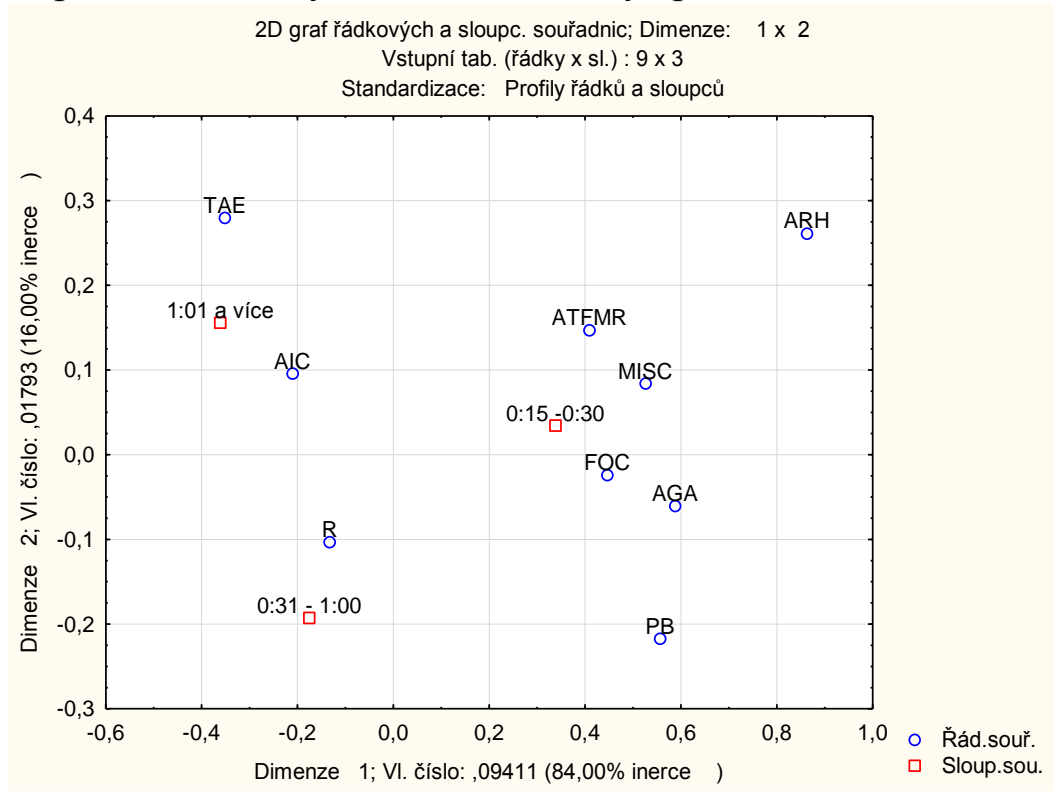

Zdroj: vlastní výpočty

Z další analýzy je patrné, jaké důvody zpoždění (viz tabulka 4) převažují na jednotlivých sledovaných letištích. Důvod AIC se maximálně vyskytuje v Praze (20\%), jinde zanedbatelně. Důvody PB a ARH se celkově vyskytují velmi zřídka. S cestujícími a jejich zavazadly tedy většinou problémy nejsou ani na jednotlivých letištích v ČR. Důvody TAE, FOC a AGA jsou nejčastější v Praze, na jiných letištích jsou tyto důvody méně časté. V Praze je technická báze, tedy opravy letadel probíhají zejména na tomto letišti, proto je zde nejčastěji zpoždění způsobené technickou údržbou letadel. V Praze je též nejvíce zpoždění způsobených operačním řízením a letovými normami posádek, zřejmě proto, že je zde nejvíce odletů celkem. Důvod AGA lze vysvětlit intenzitou provozu na letišti v Praze. Důvod ATFMR je na tom velmi podobně, o trochu častější je v Praze. Př́ičinou jsou zřejmě přeplněné sloty - letový prostor v okolí Prahy je mnohem více zahuštěný než na ostatních letištích. Důvod R se vyskytuje celkově velmi často, výrazně častější je v Brně a v Ostravě, kolem $80 \%$, v Praze pouze $41 \%$. V Praze se totiž uskutečňuje snáze optimalizace zpoždění díky většímu počtu letadel.

$\mathrm{Z}$ důvodu malých četností v kontingenční tabulce nebylo možné provést Pearsonův test ani korespondenční analýzu.

Tabulka 4: Kontingenční tabulka - Sloupcové relativní četnosti: Závislost důvodů zpoždění na konkrétním letišti

\begin{tabular}{|l|c|c|c|}
\hline & PRG & BRQ & OSR \\
\hline AIC & $19,79 \%$ & $2,78 \%$ & $0,52 \%$ \\
PB & $2,41 \%$ & $0,00 \%$ & $1,55 \%$ \\
ARH & $1,63 \%$ & $0,00 \%$ & $0,00 \%$ \\
TAE & $10,03 \%$ & $3,24 \%$ & $4,64 \%$ \\
FOC & $6,12 \%$ & $4,63 \%$ & $2,58 \%$ \\
ATFMR & $10,16 \%$ & $8,33 \%$ & $8,25 \%$ \\
AGA & $5,99 \%$ & $0,46 \%$ & $1,03 \%$ \\
R & $41,47 \%$ & $76,39 \%$ & $80,93 \%$ \\
MISC & $2,41 \%$ & $4,17 \%$ & $0,52 \%$ \\
\hline
\end{tabular}

Zdroj: vlastní výpočty 
Pomocí Pearsonova chí-kvadrát testu nezávislosti jsme dále testovali vztah mezi proměnnými značícími důvody zpoždění letů a dobu odletů. Při testování nezávislosti byla vypočtena hodnota testové statistiky $\chi^{2}=545,08$ s p-hodnotou $p=0,00$. Na $5 \%$ hladině významnosti tedy zamítáme nezávislost obou sledovaných proměnných. Charakter závislosti je patrný $\mathrm{Z}$ relativních četností $\mathrm{v}$ kontingenční tabulce $\mathrm{i}$ z korespondenční mapy (viz tabulka 5, obrázek 2). Pearsonův koeficient kontingence je $P=0,4678$. Ze sledovaných závislostí je $\mathrm{v}$ tomto př́padě intenzita závislosti nejvyšší.

Tabulka 5: Kontingenční tabulka - Sloupcové relativní četnosti: Závislost důvodů zpoždění na denní době odletu letadel

\begin{tabular}{|l|c|c|c|c|}
\hline & $\mathbf{0 : 0 1}-\mathbf{6 : 0 0}$ & $\mathbf{6 : 0 1}-\mathbf{1 2 : 0 0}$ & $\mathbf{1 2 : 0 1}-\mathbf{1 8 : 0 0}$ & $\mathbf{1 8 : 0 1} \mathbf{- 2 4 : 0 0}$ \\
\hline AIC & $2,61 \%$ & $20,39 \%$ & $17,10 \%$ & $13,45 \%$ \\
PB & $2,61 \%$ & $1,70 \%$ & $0,72 \%$ & $6,73 \%$ \\
ARH & $3,73 \%$ & $0,78 \%$ & $0,72 \%$ & $1,79 \%$ \\
TAE & $20,15 \%$ & $8,24 \%$ & $4,64 \%$ & $9,42 \%$ \\
FOC & $20,15 \%$ & $4,05 \%$ & $2,61 \%$ & $2,69 \%$ \\
ATFMR & $25,75 \%$ & $6,54 \%$ & $5,94 \%$ & $13,45 \%$ \\
AGA & $11,94 \%$ & $4,05 \%$ & $2,75 \%$ & $5,83 \%$ \\
R & $6,72 \%$ & $52,81 \%$ & $64,06 \%$ & $42,60 \%$ \\
MISC & $6,34 \%$ & $1,44 \%$ & $1,45 \%$ & $4,04 \%$ \\
\hline
\end{tabular}

Zdroj: vlastní výpočty

Obrázek 2: Korespondenční analýza: Závislost důvodů zpoždění na denní době odletu letadel

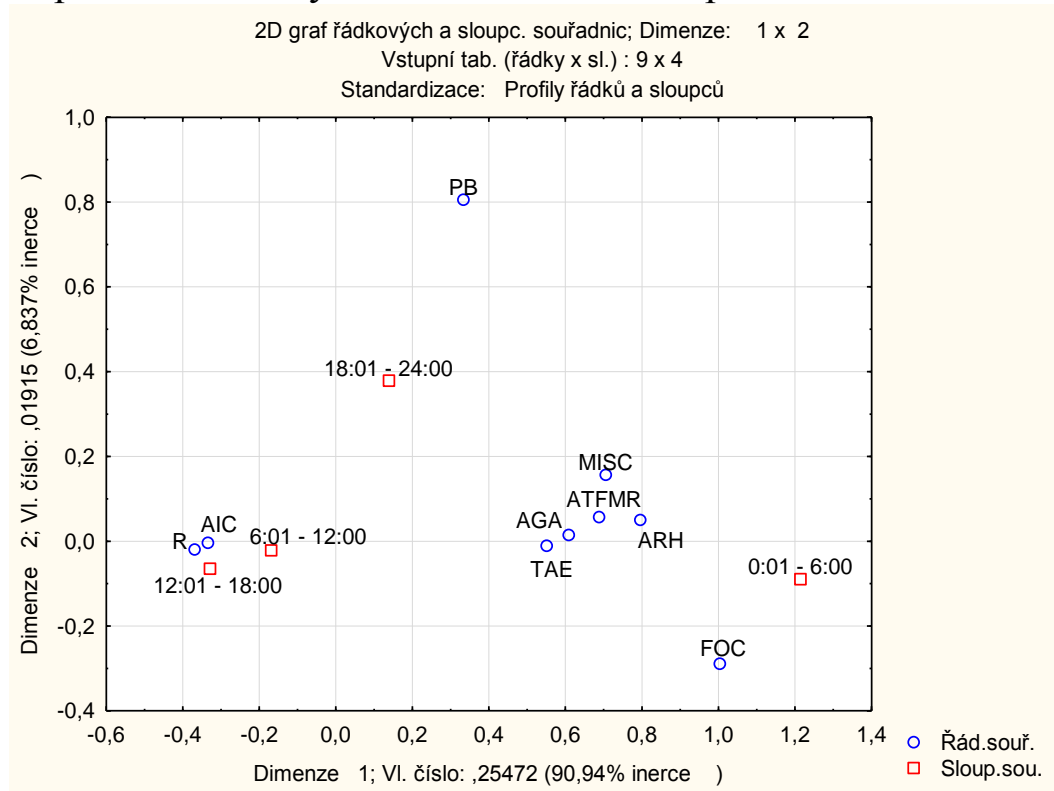

Zdroj: vlastní výpočty

Důvod AIC se minimálně vyskytuje v nočních hodinách (necelá $3 \%$ ), nejčastější je to důvod během dne 6:01 - 18:00 hod. (17 - 20 \%). Důvod PB se celkově vyskytuje velmi zřídka, nejčastější je ve večerních hodinách od 18:01 - 24:00 hod. (necelých $7 \%$ ). S cestujícími a jejich zavazadly tedy většinou problémy nejsou. Důvod ARH se rovněž vyskytuje minimálně, nejčastěji během noci 0:01 - 6:00 hod. (necelá $4 \%$ ). V noci se zřjejmě dodavatelským společnostem nedaří plně zajišt'ovat servis. Důvody TAE a FOC jsou výrazně častější během noci 0:01 - 6:00 hod. (20\%). V noci se většinou dělají servisní prohlídky, nebot' poptávka po letadlech je nižší, je proto prostor k náročnějším servisním úkonům. $\mathrm{V}$ prípadě výpadku člena posádky je problém v nočních hodinách s náhradními kapacitami 
zaměstnanců. Důvod AGA má podobný vývoj během dne, pouze je méně častý v noci (12\%). Zpoždění může být zřejmě způsobeno lokálními omezeními na cílových letištích (stávky, kapacita letiště, čekání na uvolnění stání pro letadlo, ...). V noci je z tohoto důvodu zpoždění méně časté, protože letový provoz není tak intenzivní. Důvod ATFMR je na tom velmi podobně, nejčastěji se vyskytuje v noci 0:01 - 6:00 hod. (26\%) a také večer 18:01 - 24:00 hod. (přes $13 \%$ ). Př́íčinou může být skutečnost, že v časových obdobích 4:00 - 6:00 hod. a 18:00 - 21:00 hod. jsou kapacity vzdušného prostoru letišt' nejvíce vytížené. Důvod $\mathrm{R}$ se vyskytuje celkově velmi často, nejčastější je odpoledne 12:01 - 18:00 hod. (64\%), méně častý dopoledne 6:01 - 12:00 hod. (53 \%), večer je to $43 \%$, minimálně se tento důvod vyskytuje v noci $(7 \%)$. Během noci celkově létá nejméně letadel, proto je tento důvod zpoždění velmi vzácný. Nejvíce letů probíhá během odpoledne, proto je tento důvod patrně nejčastější právě v odpoledních hodinách.

Dále jsme pomocí Pearsonova chí-kvadrát testu nezávislosti testovali vztah mezi proměnnými značícími důvody zpoždění letů a sledované období (červen, červenec, srpen, záŕí). Při testování nezávislosti byla vypočtena hodnota testové statistiky $\chi^{2}=60,82$ s p-hodnotou $p=0,00$. Na $5 \%$ hladině významnosti tedy zamítáme nezávislost obou sledovaných proměnných. Charakter závislosti je patrný z relativních četností v kontingenční tabulce i z korespondenční mapy (viz tabulka 6, obrázek 3). Pearsonův koeficient kontingence je $P=0,1741$.

Z analýzy relativních četností v kontingenční tabulce je patrné, že důvod AIC převažuje v zárí (23\%), v ostatních měsících kolem $14 \%$. V zárí má společnost menší počet letadel (byla vrácena pronajatá letadla). $\mathrm{V}$ důsledku toho musejí být zbylá letadla více vytěžována a jsou pro ně naplánovány kratší průletové časy (doba, kterou letadlo stojí na zemi mezi príletem a odletem). Tato doba, často např. 30 minut, obvykle nebývá dodržena a vznikají zpoždění. Důvody PB a ARH se vyskytují celkově zřídka a výrazněji se během období neliší. Důvod TAE převažuje v červenci (13\%), jinak kolem $7 \%$. Protože je v červenci celkově nejvíce letů, vyskytuje se nejvíce technických problémů a je nutná častější údržba. Výskyt důvodu FOC se během sledovaného období výrazně neliší, pohybuje se kolem $5 \%$. Dủvod ATFMR převažuje v září $(12 \%)$ a srpnu (10 \%). Možnou př́ičinou může být horší počasí v destinacích. Výskyt důvodu $\mathrm{R}$ se výrazněji nemění a pohybuje se kolem $50 \%$. O trochu častější je $\mathrm{v}$ červnu a červenci. Vzhledem $\mathrm{k}$ přetížení letišt' $\mathrm{v}$ červnu a červenci je i větší množství zpožděných letadel na odletu z předchozí destinace a dochází k řetězení zpoždění.

Tabulka 6: Kontingenční tabulka - Sloupcové relativní četnosti: Závislost důvodů zpoždění na sledovaném období

\begin{tabular}{|l|c|c|c|c|}
\hline & červen & červenec & srpen & září \\
\hline AIC & $12,57 \%$ & $14,16 \%$ & $15,16 \%$ & $22,59 \%$ \\
PB & $2,16 \%$ & $1,06 \%$ & $2,56 \%$ & $2,41 \%$ \\
ARH & $1,96 \%$ & $1,27 \%$ & $1,18 \%$ & $0,66 \%$ \\
TAE & $7,86 \%$ & $12,68 \%$ & $7,87 \%$ & $6,58 \%$ \\
FOC & $5,11 \%$ & $6,55 \%$ & $6,10 \%$ & $4,61 \%$ \\
ATFMR & $8,06 \%$ & $8,88 \%$ & $10,24 \%$ & $12,06 \%$ \\
AGA & $6,48 \%$ & $3,81 \%$ & $5,91 \%$ & $3,07 \%$ \\
R & $51,67 \%$ & $50,11 \%$ & $48,62 \%$ & $46,49 \%$ \\
MISC & $4,13 \%$ & $1,48 \%$ & $2,36 \%$ & $1,54 \%$ \\
\hline
\end{tabular}


Obrázek 3: Korespondenční analýza: Závislost důvodů zpoždění na sledovaném období

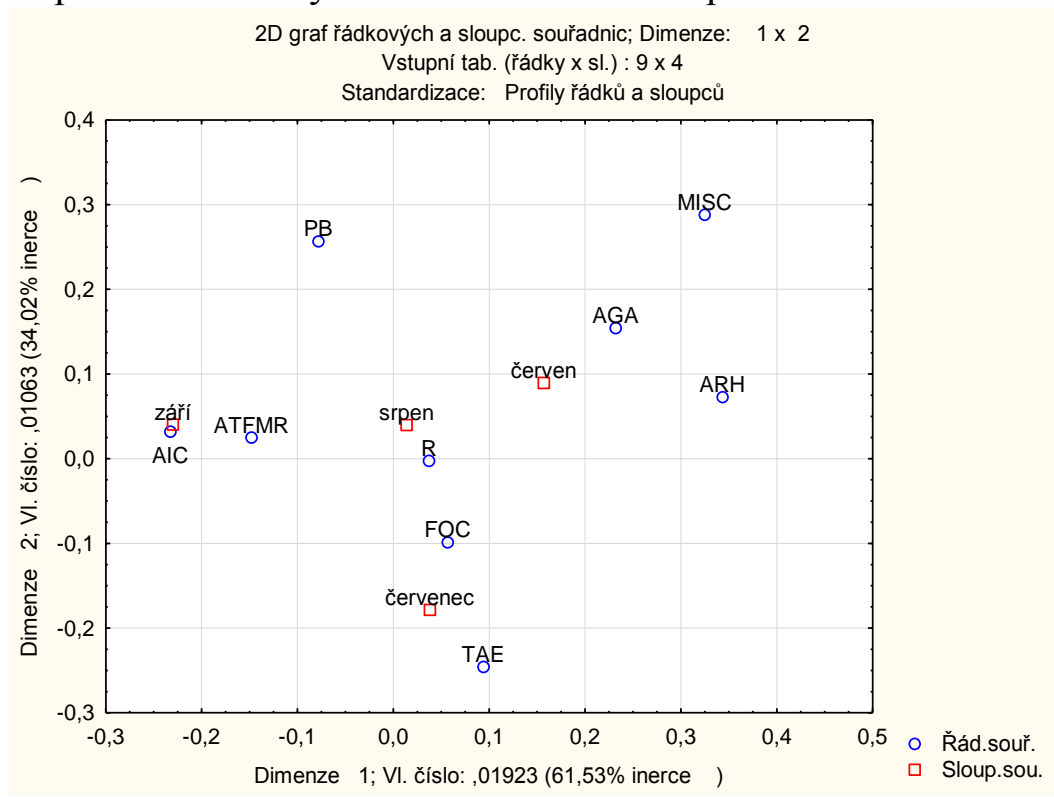

Zdroj: vlastní výpočty

Pomocí Pearsonova chí-kvadrát testu nezávislosti jsme dále testovali vztah mezi proměnnými značícími důvody zpoždění letů a dobu př́letů zpožděných letů. Při testování nezávislosti byla vypočtena hodnota testové statistiky $\chi^{2}=52,44 \mathrm{~s}$ p-hodnotou $p=0,00$. Na $5 \%$ hladině významnosti tedy zamítáme nezávislost obou sledovaných proměnných. Charakter závislosti je patrný z relativních četností v kontingenční tabulce i z korespondenční mapy (viz tabulka 7, obrázek 4). Pearsonův koeficient kontingence je $P=0,1496$.

Z kontingenční tabulky i z korespondenční mapy je zřejmé, že u př́letů výrazně převažuje zpoždění z důvodu pozdního odletu z předchozí destinace, tento důvod tvoří kolem $90 \%$ všech zpoždění. Důvody PB a ARH se celkově vyskytují velmi zřídka a výrazněji se neliší. Důvody zpoždění AIC, TAE a FOC jsou nejčastější v Ostravě. Důvod zpoždění ATFMR je častější v Praze, což je podobná situace jako u odletů, nebot' letový prostor v okolí Prahy je mnohem více zahuštěný než na ostatních sledovaných letištích.

Tabulka 7: Kontingenční tabulka - Sloupcové relativní četnosti: Závislost důvodů zpoždění na príletech zpožděných letů

\begin{tabular}{|l|c|c|c|}
\hline & Přilet na PRG & Přilet na BRQ & Přilet na OSR \\
\hline AIC & $0,73 \%$ & $0,59 \%$ & $3,50 \%$ \\
PB & $1,14 \%$ & $1,18 \%$ & $1,50 \%$ \\
ARH & $0,47 \%$ & $0,59 \%$ & $0,00 \%$ \\
TAE & $0,83 \%$ & $2,96 \%$ & $4,00 \%$ \\
FOC & $0,83 \%$ & $1,18 \%$ & $3,50 \%$ \\
ATFMR & $2,76 \%$ & $1,18 \%$ & $1,50 \%$ \\
AGA & $1,82 \%$ & $1,18 \%$ & $0,50 \%$ \\
R & $90,07 \%$ & $89,35 \%$ & $83,50 \%$ \\
MISC & $1,35 \%$ & $1,78 \%$ & $2,00 \%$ \\
\hline
\end{tabular}

Zdroj: vlastní výpočty 
Obrázek 4: Korespondenční analýza: Závislost důvodů zpoždění na př́letech zpožděných letů

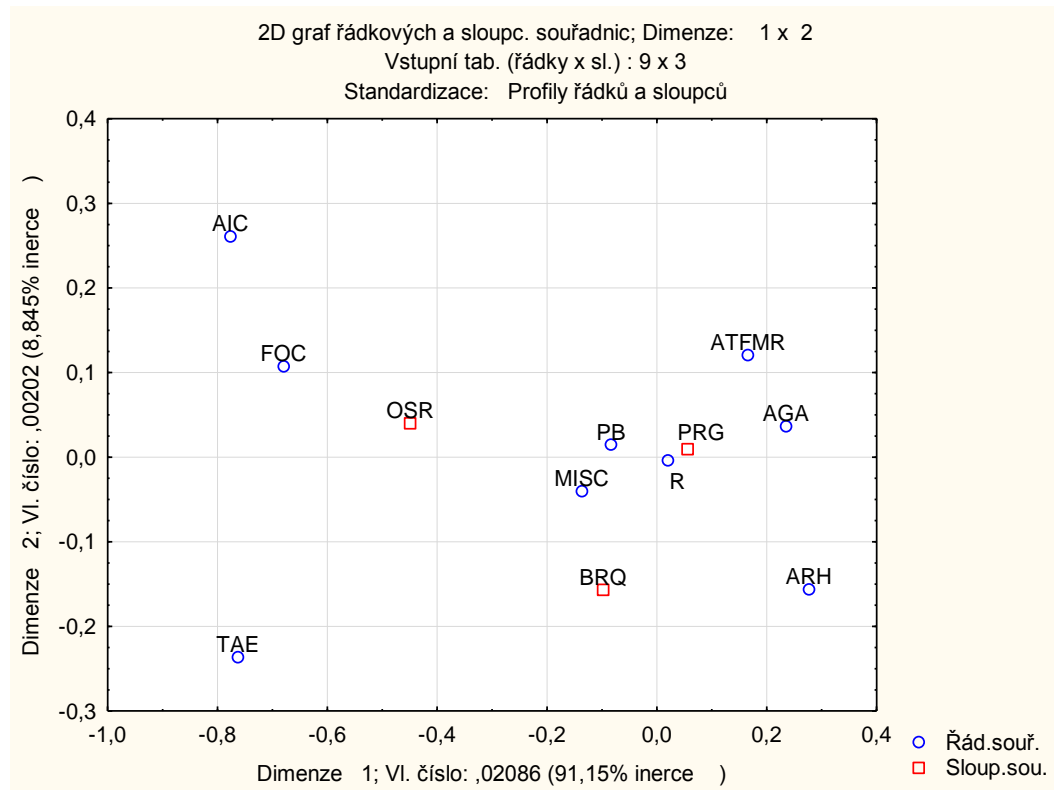

Zdroj: vlastní výpočty

\section{Diskuze a závěr}

Zpoždění letadel způsobuje pro leteckou společnost značné finanční náklady na kompenzace pro cestující. Některé př́činy se dají ovlivnit pouze obtížně nebo vůbec, např. přeprava tělesně postižených osob, potřeba ošetřit cestujícího s náhlým zdravotním problémem atd. Tyto důvody ze zákona neznamenají nutnost vyplácet odškodné. Nicméně zpožděný let $\mathrm{z}$ těchto důvodů může způsobit další řetězení zpoždění pro následující lety a zde je již nutné odškodnění cestujícím vyplatit. Tyto důvody jsou závažné, protože zpoždění $z$ těchto príčin dle našeho výzkumu bývají dlouhá a je proto nutno vyplácet velmi vysoké odškodnění.

S cestujícími, jejich zavazadly a odbavením letadel dodavatelskými společnostmi nejsou výraznější potíže. Z výzkumu vyplynulo, že tato zpoždění se vyskytují jednak poměrně vzácně, zároveň bývají kratší než 30 minut. Dodavatelské společnosti se zřejmě snaží minimalizovat zpoždění z jejich viny, jinak mohou být penalizovány. Dále jsme zjistili, že tyto důvody jsou o něco častější v Praze, pravděpodobnou příčinou může být výrazně hustší provoz právě na pražském letišti. Zde bychom letecké společnosti doporučili, zda formou dalších vhodných penalizací dodavatelských společností nedocílit ještě rychlejšího odbavení letadel a tím uspořit čas a předejít zpoždění a ztrátě finančních prostředků.

Zpoždění způsobená technickou údržbou a závadami na letadle jsou pouze částečně ovlivnitelná důkladným servisem. Taková zpoždění jsou z ekonomického hlediska velmi závažná, z provedené analýzy vyplynulo, že jsou většinou delší než 1 hodinu. První zpožděný let $\mathrm{z}$ technických důvodů neznamená nutnost odškodnění pro cestující, ale opět často dochází k dalšímu řetězení zpoždění. Na následujících zpožděných letech je již pak nutné finanční kompenzace cestujícím vyplácet. V Praze je technická báze, opravy letadel probíhají zejména na tomto letišti, proto je zde dle výzkumu (oproti Brnu a Ostravě) častější příčinou zpoždění právě technická údržba letadel. Dále bylo prokázáno, že údržba letadel se na důvodech zpoždění nejčastěji podílí během noci v čase 0:01 - 6:00 hod. V noci se většinou dělají servisní prohlídky, nebot' poptávka po letadlech je nižší, je proto prostor k náročnějším servisním úkonům. Též bylo analýzou zjištěno, že technické problémy způsobují zpoždění nejčastěji v červenci, zrrejmě proto, že v červenci je celkově nejvíce letů. 
Doporučujeme proto technické problémy nepodceňovat a servisní prohlídky provádět pravidelně a odstraňovat ihned i drobné závady. Ty totiž mohou představovat $\mathrm{v}$ budoucnu hrozbu výskytu rozsáhlejšího problému a odstávku letadla na dlouhou dobu, což pro aerolinky není z finančního hlediska výhodné. Současně je nutné vzít v úvahu, že se letadlo může stát neletuschopným v nějaké cizí destinaci, kde oprava bude stát aerolinky mnohem více prostředků, než oprava v Čechách. Též např. v této dovolenkové destinaci nemusí být vůbec potřebný náhradní díl $\mathrm{k}$ dispozici a následná doprava náhradního dílu $\mathrm{k}$ letadlu se může velmi prodražit. Společnost navíc ztratí další finanční prostředky z důvodu náhrad cestujícím $\mathrm{v}$ důsledku výpadku letadla z provozu. Je tedy velmi vhodné investovat do údržby letadel, aby byla $\mathrm{v}$ perfektním stavu. Alespoň v rámci poruch, kterým jde údržbou předejít. Náhodné poruchy ovlivnit samožrejmě nelze. Vzhledem $\mathrm{k}$ vysokým kompenzacím při delších zpožděních je to určitě dobrá investice.

V Praze je pak dle analýzy nejvíce zpoždění způsobených operačním řízením a letovými normami posádek, zřejmě proto, že je zde nejvíce odletů celkem. Tento důvod převládá dle výzkumu v nočních hodinách. $\mathrm{V}$ př́ípadě výpadku člena posádky je patrně problém v nočních hodinách s náhradními kapacitami zaměstnanců. Personál není významnějším problémem, protože dle našeho výzkumu způsobuje obvykle pouze kratší zpoždění do 30 minut. Nicméně i zde lze eliminovat možné nedostatky formou vhodných školení a následnou examinací tedy odstraněním zpoždění způsobených lidskou chybou. Současně především v červenci, kdy je nejvíce letů, doporučujeme zvážit možnost nějakých erudovaných posil, např. formou částečných úvazkủ. Též doporučujeme uvážit především v nočních hodinách myšlenku zaměstnance na telefonu, který by byl velmi rychle $\mathrm{k}$ dispozici při výpadku nějakého člena posádky.

Dle výzkumu se řízení letového provozu na vzniklých zpožděních nejvýrazněji podílí u krátkých zpoždění do 30 minut. Vzdušný prostor je regulován centrálním řízením, které se snaží o plynulý a ekonomický provoz. Zpoždění způsobené řízením letového provozu převládá v Praze, prŕčinou jsou patrně přeplněné sloty (letový prostor v okolí Prahy je mnohem více zahuštěný než na ostatních letištích). Dále se tento důvod zpoždění nejčastěji vyskytuje v noci v čase 0:01 - 6:00 hod. a také večer v čase 18:01 - 24:00 hod. Př́ičinou může být skutečnost, že v časových obdobích 4:00 - 6:00 hod. a 18:00 - 21:00 hod. jsou kapacity vzdušného prostoru letišt' nejvíce vytížené.

Obtížně ovlivnitelným důvodem zpoždění je nepříznivé počasí na cílových nebo odletových letištích. Především v srpnu a záŕí může být příčinou delších zpoždění horší počasí jak v cílových destinacích, tak na našich letištích. Dále bylo prokázáno, že zpoždění v důsledku omezení na letištích má podobný vývoj během dne, pouze je méně časté v noci. To může být zřejmě způsobeno lokálními omezeními na cílových letištích (stávky, kapacita letiště, čekání na uvolnění stání pro letadlo, ...). V noci je z tohoto důvodu zpoždění méně časté, protože letový provoz není tak intenzivní.

Zpoždění způsobené zpožděním předcházejících letů se dle výzkumu vyskytuje celkově velmi často, výrazně častější je v Brně a v Ostravě, kolem $80 \%$, v Praze pouze 41 \%. V Praze se uskutečňuje snáze optimalizace zpoždění díky většímu počtu letadel a možnosti náhrady. Důvod se minimálně vyskytuje v noci kvůli celkově malému počtu letů a minimálnímu riziku řetězení zpoždění. V souvislosti s vyplácením finančních náhrad doporučujeme promyslet možnost náhradního letadla (bez letového plánu), které by bylo $\mathrm{k}$ dispozici v případě nutnosti. Př́ípadně by to mohlo být jen v nejfrekventovanějších měsících (červen, červenec, srpen). Samozřejmě je nutné zvážit a důkladně propočítat, co je ekonomicky výhodnější v př́ípadě 
dlouhých zpoždění - náhradní letadlo nebo finanční kompenzace cestujícím. Současně zde spatřjujeme možnost další analýzy, kde v „dovolenkových“ destinacích nejčastěji dochází k dlouhým zpožděním a jak by bylo vhodné tato zpoždění eliminovat a tím uspořit další finanční prostředky.

Zatímco článek autorů Skorupski, Wierzbinska (2015) se zabývá potížemi vzniklými čekáním na opožděné cestující, z naší analýzy vyplynulo, že na českých letištích zpožděný cestující nepředstavuje významnější problém. Podle autorů Forbes, Lederman, Tombe (2015) by bylo vhodné, aby aerolinky zveřejňovaly informace o množství zpožděných letů se zpožděním delším než 15 minut. Dle našeho názoru by bylo velmi vhodné, aby všechny letecké společnosti uváděly tyto údaje veřejně, bylo by to prospěšné jak pro cestující, tak pro samotné společnosti, které by $\mathrm{v}$ rámci konkurenceschopnosti na základě těchto dat mohly zlepšit vnitřní firemní postupy. Závěry tohoto výzkumu byly konzultovány s odborníkem pracujícím v letecké společnosti.

\section{Literatura}

[1] AGRESTI, A., 1990. Categorical Data Analysis. New York: John Wiley a Sons. ISBN 0471-36-093-7.

[2] ANDĚL, J., 2005. Základy matematické statistiky. Praha: Matfyzpress. ISBN 978-807378-1620.

[3] EUROCONTROL, 2015. Central Office for Delay Analysis [online]. [vid. 2. záŕí 2015]. Dostupné z: www.eurocontrol.int/articles/central-office-delay-analysis-coda

[4] EUROPEAN CONSUMER CENTRE CZECH REPUBLIC, 2015. Laws on Air Transport [online]. [vid. 5. září 2015]. Dostupné z: www.evropskyspotrebitel.cz /eng/letecka-doprava/letecka-doprava-predpisy-27143

[5] FORBES, S. J., M. LEDERMAN a T. TOMBE, 2015. Quality Disclosure Programs and Internal Organizational Practices: Evidence from Airline Flight Delays. American economic journal - microeconomics, 7(2), 1-26. ISSN 1945-7669.

[6] GREENACRE, M. J., 1984. Theory and Applications of Correspondence Analysis. London: Academic Press. ISBN 978-0122990502.

[7] HEBÁK, P., 2007. Vicerozměrné statistické metody 3. Praha: Informatorium. ISBN 97880-7333-039-2.

[8] HENDL, J., 2006. Přehled statistických metod: analýza a metaanalýza dat. Praha: Portal. ISBN 978-80-7367-482-3.

[9] HINDLS, R., 2003. Statistika pro ekonomy. Praha: Professional Publishing. ISBN 8086419-34-7.

[10] ŘEZANKOVÁ, H., 1997. Analýza kategoriálních dat pomocí SPSS. Praha: VŠE. ISBN 807-079-7282.

[11] SKORUPSKI, J. a M. WIERZBINSKA, 2015. A method to evaluate the time of waiting for a late passenger. Journal of air transport management, 47, 79-89. ISSN 0969-6997.

[12] WU, C. a T. TRUONG, 2014. Improving the IATA delay data coding system for enhanced data analytics. Journal of air transport management, 40, 78-85. ISSN 09696997. 